University of South Florida

DIGITAL COMMONS

Digital Commons @ University of

@ UNIVERSITY OF SOUTH FLORIDA

South Florida

2006

\title{
Supranational Networks: States and Firms
}

Alvin W. Wolfe

University of South Florida, wolfe@cas.usf.edu

Follow this and additional works at: https://digitalcommons.usf.edu/ant_facpub

Part of the Anthropology Commons

\section{Scholar Commons Citation}

Wolfe, Alvin W., "Supranational Networks: States and Firms" (2006). Anthropology Faculty Publications. 1. https://digitalcommons.usf.edu/ant_facpub/1

This Article is brought to you for free and open access by the Anthropology at Digital Commons @ University of South Florida. It has been accepted for inclusion in Anthropology Faculty Publications by an authorized administrator of Digital Commons @ University of South Florida. For more information, please contact digitalcommons@usf.edu. 


\title{
SUPRANATIONAL NETWORKS: STATES AND FIRMS
}

\author{
Alvin W. Wolfe
}

\begin{abstract}
The nation-state systems that seem to dominate the global landscape are not necessarily the pinnacle of evolution. A conglomeration of interacting factors spelled doom for the traditional colonialism of previous centuries while providing an ideal environment for multinational firms operating above the level of nation-states to play an important role in the generation of a new politico-socio-economic system better described by network models than by ordinary political models. Previously existing units and subunits, in the course of adjustment and adaptation to changing circumstances, change their relations with one another and are, sometimes, newly integrated in a novel manner such that new units or subunits are recognizable.

It is puzzling that most scholars still see these changes as merely quantitative growth rather than as a qualitatively new system at a supranational level of integration. Because human beings start from concepts we already know, one really has to be strongly motivated to try to go beyond the cognitive concepts one uses regularly to attempt to conceive of something different. In the perspective of millions of years of evolution both states and business firms are relatively recent emergents out of the processes of adaptation that generate all social formations. Both business firms and nation states are kinds of corporations, and it is a mistake to deal separately with the international network of states when it seems perfectly obvious that the supranational system includes interacting states and corporations in a single complex network. Most countries are not "natural" nation-states, but are corporations whose control over some territory is recognized by some other states. States and companies should be treated similarly in analysis of the supranational system and the best model for studying the supranational system is a network model that begins with defining units and their relationships. In that mode, applying various mathematical algorithms, one can find clusters and equivalence sets representing different levels of organization in the network. At the same time as states are influencing firms, firms are busily influencing states.
\end{abstract}

\section{Introduction}

During the past 25 years I have from time to time expressed a persistent theme, namely that the nation-state systems that seem to dominate the sociocultural landscape are not necessarily the pinnacle of evolution. Their preeminent position is being eroded as new forms of organization are generated at a higher level. The relative equilibrium of the international system was punctuated, one might say, following World War II and especially during the 1960s when a conglomeration of interacting factors spelled doom for the traditional colonialism of the previous centuries while providing an ideal environment for industry and commerce on a global scale. Multinational firms operating above the level of nation-states play an important role in the generation of this new politico-socio-economic system. The new system is better described by network models than by ordinary social system models. The flow of information and the control of resources in the network must be traced if the emerging system is to be described and understood. 
I first encountered the new system a quarter century ago when I studied the chaotic events through which Congo became Zaire (Wolfe 1962,1963). I saw how states were weakened relative to companies that were able to operate above the level at which states ordinarily have sovereignty, and I illustrated my reports on the process with data from the nonferrous metals industries that operated in what are now Zaire, Zambia, Zimbabwe and Angola but were largely controlled from Belgium, Great Britain, the Republic of South Africa and the United States. Figure 1 reproduces one of those illustrations from 1962.

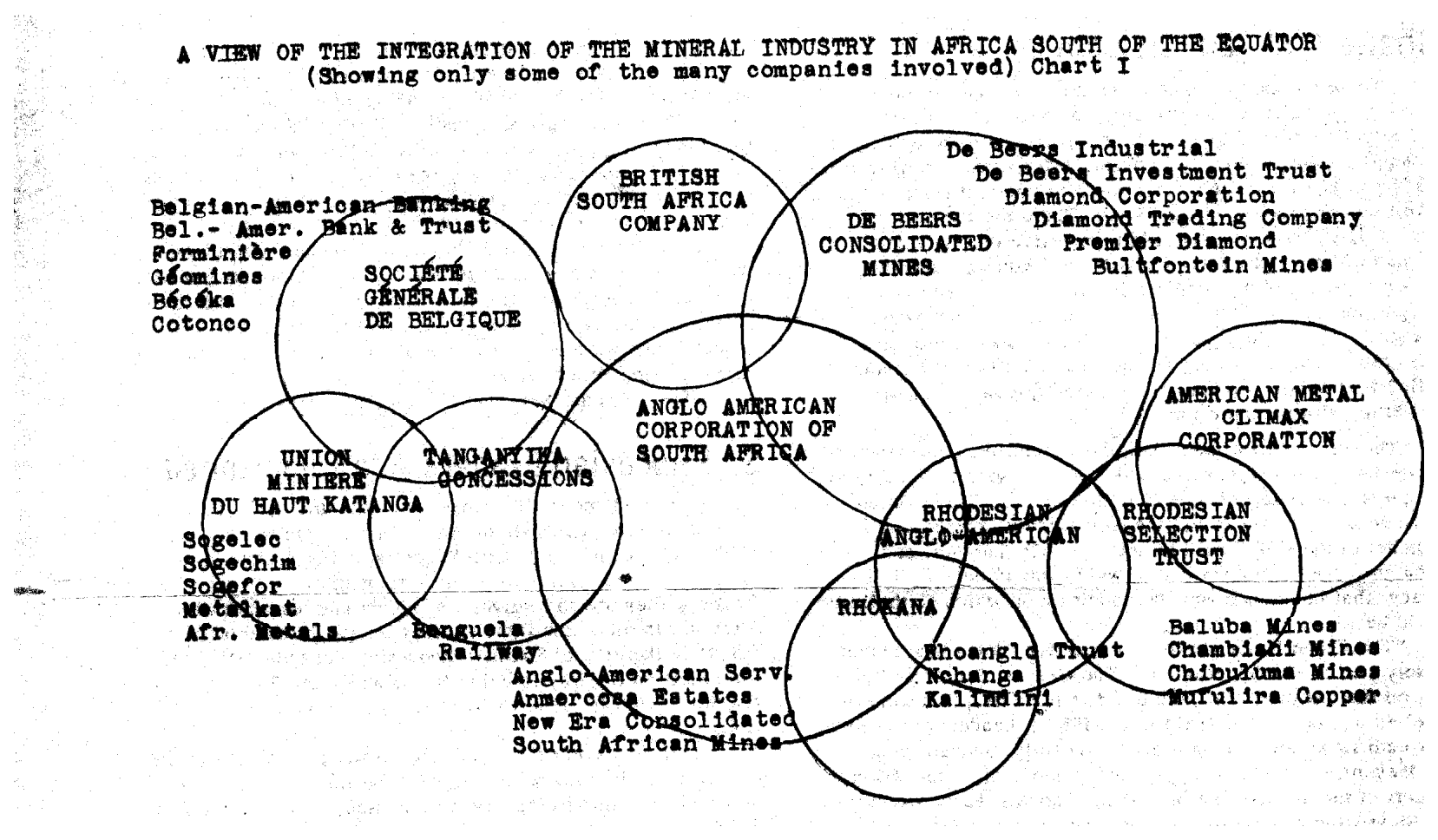

Figure 1. Perspectives on the Supranational Integration of the mining industry in southern Africa, 1962.

Those observations were for me clear illustrations of the more general processes by which new social phenomena are generated: Previously existing units and subunits, in the course of adjustment and adaptation to changing circumstances, change their relations with one another and are, sometimes, newly integrated in a novel manner such that new units or subunits are recognizable.

As the years have gone by there have been scores of studies of multinational enterprise by scholars from many disciplines. I see now more and more evidence of the evolutionary changes I had foreseen then. But I find it puzzling that most scholars still see these changes as merely a matter of quantitative growth, not, as I see them, as having initiated a qualitatively new system at a supranational level of integration. 
I have been trying to figure out what it is that prevents social scientists, even anthropologists, from envisioning something genuinely new.

\section{Difficulties of Thinking Anew}

Unfortunately, we human beings have to start from concepts we already know. That is the crux of the problem right there. One really has to be strongly motivated to try to go beyond the cognitive concepts one uses regularly to attempt to conceive of something different. We, even we anthropologists, are limited in what we may think. Cultural relativism means just that. The principle of relativism applies, even to those of us who strive to be universalistic, scientific, above it all: "Judgments are based on experience and experience is interpreted by each in terms of his own enculturation" (Herskovits 1955). We can easily adjust from seeing the glass half empty to seeing the glass half full, but it strains us a bit to hear, from George Carlin, that the glass is really twice as large as it needs to be.

If anybody can shake loose the shackles that bind us mentally and mechanically from appropriately interpreting events of the modern world it should be anthropologists. One of the obstacles to our understanding the wider systems of the modern world, call them supranational systems or world systems or systems of international scope, is that common concepts like state, nation-state, country, and firm, company, and corporation are imbued with cultural meanings that have been fixed not only in our languages and minds but also in our institutional memories as well. We put states and business firms in completely separate boxes, making it difficult to see that their interactions are generating a system at a level of integration that I call supranational, above the level of any given nation.

While states and business firms have been around for some thousands of years, in the perspective of millions of years of evolution these are both relatively recent emergents from the processes of adaptation that generate all social formations. Anthropologists have not given these forms the kind of attention we have lavished on institutions of family and kinship and community. Now, when it is critical that we understand them and their relations, we seem to be accepting the wisdom of conventional political scientists and economists. We have not subjected these concepts -- business firm, corporation, state -- to analysis in the light of our own comparative and emic/etic perspectives.

I was pleased some years ago to see James Dow's (1973) discussion of what he labeled the "muddled concept of corporation." Unfortunately, not many picked up on his call for "the reformulation of a concept of corporation that will be more precise and useful to social anthropology" (1973:906). We are no better off now. Perhaps worse, because now I see no discussion whatsoever of the issues in which I am interested. But while I applaud Dow's intentions that we should be clear about whatever we talk about, I believe the need right now is for a general concept referring to a generalized social formation or cultural construction general enough to include the variations which are in fact presenting the evolutionary options we are trying to understand. We need a general concept that will encompass all forms of social formations that control persons, resources, and benefits, to use Nadel's (1951) terms. 
M.G. Smith (1974) intended the concept of corporation to provide a framework for the study of all human organization. I agree that we have such a need. Smith, however, might not agree with me that the ordinary business firm or company is as good an example of the general type as is the nation-state. I say that not because Smith explicitly excluded business firms from the category of social units he called corporations, but only because in his 383-page book entitled Corporations and Society I can find no mention of a business firm or company. The "notion of corporations that informs (his) essays" was certainly broad enough: "All social units assumed to be perpetual and identified by distinct autonomies within given spheres which have the organization necessary to manage these affairs, (and) are units with a public character and capacity" (1974:85).

A more recent case demonstrating the need to clarify our thinking about states and corporations in international trade is the work of David A. Smith and Douglas White presented at the Sixth Annual International Sunbelt Social Network Conference in Santa Barbara, "Change in the World Economy? A Network Analysis of International Trade: 1965-1980" (1986). They described the structure that results from analysis of the reported flow of commodities among eighty countries. Using their regular equivalence algorithm, they were pleased to find a structure that they felt generally conformed with the expectations of the world-system perspective, that is they found some countries they could label core, some they could label periphery, then some in a category called semiperiphery, which could be divided into "advanced semiperiphery" and "secondary semiperiphery" even as the core can be divided into the core, per se, and a secondary core. Finally, in comparing such analyses at different points in time and finding that some nations seem to rise or fall from one of these sub-categories into another, Smith and White believe they have information that could be useful for developing a more precise and dynamic theory of the operation of the world economy. (See also Smith and White 1988 and 1992.)

I have no argument with the method of analysis used by Smith and White. Their regular equivalence algorithm certainly appears to be the best method of identifying equivalent positions in a complex network. I am sorry to see them use such a sensitive device on data that are so grossly inadequate, and am sorry to see them associate it with a theoretical model (world system) that strikes me as being little more than a culturally constructed history having no explanatory power or prospects.

I harbor grave doubt about the prospects of successfully understanding the modern world economy by categorizing nation states into two, three, four, seven or any number of positions along a dimension of core-periphery. This is what the World System people have been talking about for fifteen years, but that is not the way the system works. Countries or nation states are not the only actors in the world economy, they are not the only nodes in the network of actors that must be taken into account. Effective actions and transactions made by multinational firms are not all subsumed within the trade statistics of one or another nation-state.

I have not seen explicit arguments that states and business firms are fundamentally different kinds of social formations, but I have noticed that most anthropological studies that deal with them at all treat them separately and independently. I just mentioned that M.G. Smith 
(1974) devoted eight essays to the subject of corporations as fundamental entities in human societies, including modern societies, and never mentioned business firms. Could it be that they were meant to be excluded? Similarly perplexing to me is the fact that Lloyd Fallers (1974) published an entire book of essays, The Social Anthropology of the Nation-State, and never mentioned the concept of corporation. Nor did he, by the way, mention business firms as having any bearing on the social anthropology of the nation-state.

For me, and in conformity with Smith's and most other definitions (Maine 1884, Weber 1947, and see Dow 1973 for others), both business firms and nation states are kinds of corporations, both companies and countries are kinds of corporations.

\section{Errors of Inaccuracy and Errors of Omission}

There are several kinds of errors here. First, there is the kind of error that Bernard, Killworth et al. (1984) hammered away at for so many years, informant inaccuracy. The governments of these states that Smith and White are studying are just about as inaccurate in their reporting of commodity trade connections as Bernard and Killworth found network informants to be. Second, there is the error that results from failure to count all the actors in the system without having any formula by which to adjust for missing data.

Since the latter part of the twentieth century, one cannot talk about the world economy without deliberately taking into account the actions and transactions of multinational firms and enterprises. Many multinational corporations are engaged in transactions of greater dollar value than the entire trade of many of the nation-states studied.

The argument has been made that every firm is included in one or another nation-state. While there is a certain legal truth in that view, there are also good reasons to view the situation differently. We are talking here about control over resources and control over persons. Of course, every corporation is registered in one or more states, and many transactions of multinational corporations are included in the statistics for countries or states, but if you really want to know about the world economy, you must also attempt to trace the decisions major corporations make about the disposition of the goods and services under their control. Multinational corporations make a variety of arrangements to assure that transactions do not appear as transactions in order to avoid duties, taxes, imposts, publicity, etc.

At the 1986 Sun Belt Social Network Conference, Linton Freeman, Kim Romney, and Sue Freeman (1986, but see also Freeman 1992) presented an interesting paper on the problem of informant accuracy. That paper has a parallel in our situation at the supranational level. "Somewhere between experience and recall," they said, "our informants were somehow warping the information about the event(s)." Freeman, Romney and Freeman explained that persons develop mental structures that reflect the regularities of their experience. Those structures then intrude on perception and recall in such a way that experiences are shaped by expectations as they are stored in memory. True as this may be for individual informants, such mechanisms operate in an exaggerated fashion as we move up from individuals through institutional levels. And when we reach that cultural construction that goes by the name of nation state those institutional memory distortions get fixed almost indelibly. I agree with anthropologist Cyril 
Belshaw's (1976) complaint that the concept of national boundary distorts our analyses of social reality. Social science interpretations are falsely biased by nationalistic assumptions and the national bases of data collection. We seem to have built national states so firmly into our culture that even a school of social history that purports to be interested in World Systems ends up merely cataloging and ranking nation-states on a core-periphery scale.

All of our institutions are biased in that way so that it is difficult to find data that are independent of the nationalist assumption. Mary Douglas makes a pithy observation in her 1986 book, How Institutions Think: "Institutions have the pathetic megalomania of the computer whose whole vision of the world is its own program" (1986:92). How appropriate an image for this network problem!

\section{The Difference between International and Supranational}

The differentiation of roles in the world economy (call it division of labor if you wish) is not just among different kinds of states. States do certain things, firms and other entities do other things, and there are interrelationships among the two kinds of units.

In the early 1960s my concern with the problems of new African states led me to study carefully the nonferrous ores and metals industry that so dominated the southern half of the continent. In a paper presented to the American Anthropological Association in 1962 I reported that the mining and metals industries there were systematically organized at what I called a "supranational" level of integration.

In 1963, I wrote:

I found the mineral extraction industry of southern Africa to be organized in an intricate ...system based more on overlapping membership of a variety of groups than on bureaucratic centralization of administrative power. The network binds groups that are different both structurally and functionally, some business corporations, some states, some families, in a modern supranational structure that is more than just international. ... The several hundred mining companies operating in southern Africa are integrated through a series of relationships that focus on some of the larger among them.... Then, in a variety of ways these corporations are linked to governments" (Wolfe 1963:153-154).

I argued then, and still defend today, the proposition that the interaction of corporations and states (and cities and families as well) is generating a genuinely new system at a level of integration above that level where states and corporations ordinarily operate. I called that a system at a supranational level of integration.

\section{The Network or System at a Supranational Level}

I think it is a mistake to consider only the relations of states and ignore non-state 
corporations operating in the world economy. Furthermore, I think it is a mistake to consider only one kind of relation, that based on the trade of commodities. As I studied the real network operating at the supranational level in southern Africa in the 1960s I saw a plexus of ties relating companies, governments, persons, institutions of many kinds. Describing the systematic nature of the network at that time I said:

No one unit can really break out in a new direction, introduce any drastic change without other units being aware of it and adjusting their own strategies. If a new development appears threatening, influences will be felt from many quarters. International financiers always rationalize their actions of granting or withholding credit by reference to market information, but they are guided by all system information within the network, not just market information. Individual businessmen who manage multinational corporations are considerably influenced by knowledge of all these interconnections. In consequence, the multinational behavior of most companies and governments is quite predictable -- systematized (1977:19-20).

Among these connections are the interlocking directorates that have been fairly well studied. But there is much more. Joint ventures are legion, especially in the mining industry, in the supranational arena. Looked at from the perspective of one company, joint ventures are risk-reduction strategies, but looked at from the perspective of the supranational system, they are linkage mechanisms that promote the integration of the system. Raymond Vernon (1974) says that joint ventures aid corporations to "move toward a common set of cost structures," and to permit them to "observe one another's competitive behavior at close range," and help to satisfy the objectives both of sharing strengths and of encouraging cooperation. States, by the way, are often partners in these joint ventures. How can one talk meaningfully of international networks without taking into account such important linkages?

Why do otherwise fine scholars continue to deal separately with the international network of states when it seems perfectly obvious that the supranational system includes interacting states and corporations in a single complex network? I feel much like Russ Bernard and Peter Killworth must have felt all those years when they kept telling us informant data are inaccurate and we kept using it anyway. I believe the problems are analogous. We use informant data anyway simply because it is available. I believe Smith and White, and all the hundreds of econometricians who play in the international trade arena, use country data simply because it is readily available, whereas truer, more realistic data are difficult to collect.

This may be the appropriate place to say something also about Fennema's (1982) study of the international networks of banks and industry, one of the few who does take seriously the relations among firms without regard to state affiliations. His study has a serious flaw of a different but related kind. By limiting the study to firms of large size Fennema must have missed many important linkages that are deliberately constructed by such mechanisms as joint ventures. Certainly among the corporations whose African interests I studied, bridges between giants existed in the form of smaller corporations controlled jointly by the larger ones. 
It should be clear that those studies of interlocking directorates, etc., internationally, suffer also from failure to take adequately into account the direct involvement of governments in linking corporations. In my studies of the system in southern Africa I found many forms of interaction between governments and the so-called private sector. Abstract network studies based on one type of tie are doomed to error.

\section{The Similarities between States and Business Firms}

Purists of one stripe or another might criticize my contention that we should include states and corporations together in the same network (international or supranational). Critics might argue that they are fundamentally different kinds of social formations. Most studies have looked separately and independently at the networks of states and business firms. I note with some approval M. Fennema's statement regarding the relations between the political and the economic, "If the analysis of the economic structure is deficient, the whole theory (of imperialism) falls apart" (1982:75).

In any event, firms and states share much more than differentiates them. A state is a kind of corporation, the kind that is ordinarily associated with a given territory and whose right to use force on that territory is recognized by some others in a general way.

Corporations that are not states differ from those that are in that their control of resources and benefits and people may not be so widely recognized. Their right to use force may not be so widely recognized, nor are they associated so strongly with a territory that defines their area of operations. It does not take much thought to appreciate that these differences are far from absolute. They are matters of degree or matters that can change in a short time.

Give a company that controls some resources the right to use force on a territory and suddenly it is a state. That is precisely what happened a hundred years ago when the International Company of the Congo, which had financed exploration and set up trading relations with peoples up and down the Congo River as a private company in 1884 was recognized by American President Chester A. Arthur as a "friendly power." Becoming a state did not require any change in form, only some change in its external relations. It did improve the standing of the company with other states, however, and that was generally good for business.

When we talk of countries and nations we tend to think they are something special and natural in the sense that they are generated by some immanent sociocultural forces. Most countries are not "natural" nation-states. They are corporations whose control over some territory is recognized by some other states. There is, furthermore, enormous variation among states, not only in size but also in mode of integration and control and in many other respects.

Most of the larger corporations in the world, say the 200 that make up the network of banks and industry that M. Fennema reported on in 1982, could be states if their right to use force over a territory were recognized by one or more current states. You might agree with me that a state's right to use force is not that much more effective than other means of exerting control over situations. All the more reason to play down the differences between companies 
and countries. Some years ago, Charles Caro (1977 unpublished personal communication) ranked corporations and states by the size of their economic product and found that 44 of the top 100 were non-state corporations. That proportion would be higher today.

Perhaps a note is in order here to explain why it is that I am so concerned that states and companies should be treated similarly. It is because the best model for studying the kind of system that they are involved in is a network model. That model begins with defining units and their relationships. Then, applying various mathematical algorithms, one can find clusters in the network, one can ascertain indices of centrality for various units or for various clusters in the network, one can identify sets of units occupying equivalent positions and, even, I hypothesize, equivalence sets representing different levels of organization in the network.

When one treats companies as a distinct class of entities, and treats countries as a distinct class of entities, one ends up, at best, with two distinct networks, the one relating companies to one another, the other relating countries to one another, with no logically simple way of relating the two networks. If I learned anything in my studies of the multinationally organized nonferrous metals industry in the 1960s it was that there are relationships between companies and states. It remains to define those relations so that they can be appropriately represented in a graph or matrix. To do this successfully, it is not necessary that all the units be identical, only that they all be represented.

Once it is recognized that countries and companies, states and business firms, have relations, the question arises as to the nature of those relations. I will not try here to identify all possible modes of those relations, nor is that necessary to benefit from the use of a network model. Among the types or modes are:

* state ownership of firm

* host country participation in ownership

* company influence on government of home country

* company influence on government of host country

* constraints applied by state where parent firm is incorporated

* constraints applied by host country

At the same time as the states are influencing the firms, the firms are busily influencing the states. The proper network model must include both companies and states. Analytic separation of these actors is formal folly.

As an example of how such general relations might be specified somewhat more, I quote nine conditions reported in a Research Report by The Conference Board, which advertises itself as "a global network of leaders who exchange information on management, economic and public policy issues" (Berenbeim 1983):

1. Local governments are attempting to limit repatriation of assets or earnings.

2. Local interests are demanding financial participation in the company enterprise, either directly or through local governments. 
3. Local governments are imposing restrictions on the company's ability to charge local units research fees for work done in its central laboratories.

4. Local interests or governments are requiring that component parts or raw materials be purchased from local suppliers.

5. Local interests or governments are demanding the company establish a research facility or transfer important technology within or to the country in which the company is doing business.

6. Local interests or governments are demanding that local nationals be appointed to top-management positions in local company operations.

7. Local governments are limiting the company's share of local markets.

8. Local governments are insisting that the company produce or sell certain products as a condition of entry into local markets.

9. Local governments are imposing limits on levels of production.

That sample of ways governments attempt to influence company decisions could easily be matched by a listing of the ways companies attempt to influence governments and other institutions in the host countries and in the home countries as well.

Clearly, understanding of this network of relations among companies and states requires collection of data on the strength of these relations in particular cases.

Organizations like The Conference Board are doing analyses from the perspectives that are important for their purposes, yielding generalizations about regional variations such as that Latin American countries figure prominently among those that demand financial participation for local interests, restrict research charges, limit repatriation of assets, and require local purchase of components or raw materials" (Berenbeim 1983: 38). Meanwhile, anthropologists and other social scientists are doing very little to clear their own agenda in order to tackle the enormous task ahead.

\section{Conclusion}

In addition to getting better control over concepts identifying the kinds of units we are dealing with and getting better control of the kinds of relations among those units, we must also seek clarification of theoretical concepts which help to distinguish levels of integration in complex systems. I have talked about relatively simply bounded entities like corporations, companies and states. We must also develop appropriate conceptual tools to handle phenomena like partnerships, limited partnerships, joint ventures and other enterprises that involve cooperation of units with some common goals. Economists and international trade scholars speak of a theory of agency that deals with relations between principals and their agents. These are some of the problems that need the light of the cross-cultural, holistic, emic perspectives of anthropology before their full implications will be understood.

\section{References Cited}


Belshaw, Cyril, 1976. The Sorcerer's Apprentice: An Anthropology of Public Policy (New York: Pergamon) .

Berenbeim, Ronald E. 1983. Operating foreign subsidiaries: How independent can they be? New York: The Conference Board.

Bernard, Russell, Peter D. Killworth, D. Kronenfeld, and Lee Sailer. 1984. The Problem of informant accuracy: The validity of retrospective data. Annual Review of Anthropology 13:495-517.

Caro, R. 1977. Personal Communication.

Douglas, Mary Tew. 1986. How Institutions Think. New York: Syracuse University Press.

Dow, James, 1973. On-the Muddled Concept of Corporation in Anthropology. American Anthropologist 75:904-.

Fallers, Lloyd A. 1974. Social Anthropology of the Nation-State. Chicago: Aldine.

Fennema, M. 1982. International Networks of Banks and Industry. The Hague: Martinus Nijhoff Publishers.

Freeman, Linton C., A. Kimball Romney, and Sue C. Freeman. 1986. Cognitive structure and informant accuracy. Paper presented at the Sixth Sun Belt Social Network Conference, Santa Barbara, California, February 1986.

Freeman, Linton C. 1992. Filling in the blanks: A theory of cognitive categories and the structure of social affiliation. Social Psych Quarterly 55(2):118-127.

Herskovits, Melville J. 1955. Cultural Anthropology. New York: Alfred A. Knopf.

Maine, Sir Henry. 1884. Ancient Law, $5^{\text {th }}$ edition. London.

Maine, Sir Henry. 1905. Ancient Law, $4^{\text {th }}$ American from $10^{\text {th }}$ London edition. New York: H.Holt \& Co.

Nadel, S. F. 1957. The Theory of Social Structure. London: Cohen and West.

Smith, David A. and Douglas R. White. 1988. World-system hegemony and trade network centrality: 1965-1980. Paper presented at the Sun Belt Social Network Conference, San Diego, February 1988.

Smith, David A. and Douglas R. White. 1992. Structure and dynamics of the global economy: Network analysis of international trade, 1965-1980. Social Forces 70(4):857-893. 
Smith, M. G. 1974. Corporations and Society: The Social Anthropology of Collective Action. Chicago: Aldine.

Vernon, Raymond. 1974. Competition policy toward multinational enterprise. American Economic Review 64:276-88.

Weber, Max. 1947. The Theory of Social and Economic Organization. Translated by A. R. Henderson and Talcott Parsons. London: Oxford.

Wolfe, Alvin W. 1962. The African mineral industry and its significance for anthropological theory. Paper presented at the $61^{\text {st }}$ Annual Meeting of the American Anthropological Association, Chicago, December 1962.

Wolfe, Alvin W. 1963. The African Mineral Industry: Evolution of a Supranational Level of Integration. Social Problems 11 (2) : 151-64.

Wolfe, Alvin W. 1977. The Supranational Organization of Production: An Evolutionary Perspective. Current Anthropology 18(4):615-635.

\section{Endnote}

This article is an expanded version of papers presented at the International Network for Social Network Analysis Sun Belt Social Network Conference, Clearwater Beach, Florida, February, 1987, and at the 86th Annual Meeting of the American Anthropological Association, in Chicago, November 20, 1987. Other works by the author on this subject are available on the web via: http://luna.cas.usf.edu/ wolfe/Supranational-AWW.html 